Jurnal e-GiGi (eG), Volume 3, Nomor 1, Januari-Juni 2015

\title{
GAMBARAN KARIES RAMPAN PADA SISWA PENDIDIKAN ANAK USIA DINI DI DESA PINELENG II INDAH
}

\author{
${ }^{1}$ Sherit Unaya Winda \\ ${ }^{2}$ Paulina Gunawan \\ ${ }^{3}$ Dinar A. Wicaksono
}

\author{
${ }^{1}$ Kandidat Skripsi Program Studi Pendidikan Dokter Gigi Fakultas Kedokteran \\ ${ }^{2}$ Program Studi Pendidikan Dokter Gigi Fakultas Kedokteran Universitas Sam Ratulangi \\ Email: nw.winda@gmail.com
}

\begin{abstract}
Rampant caries is one of the health problems of the teeth and mouth that often occurs in children. This affects the growth and development of children's teeth. Rampant caries is often found in children aged fives, and the spread of highest in children aged 3 years. The purpose of this research is to know the description of the rampant caries in student of early childhood education in the village of pineleng II indah. This is a cross-sectional research with a sample of students of the aged 3-5 years old, with 74 people. The technique of the sample used is total sampling. Examination of rampant caries was done using criteria WHO then diagnosed based on the level of expansion. The result showed that rampant caries most widely encountered is type III in 19 student (38,78\%), followed by type I in 14 student (28,57\%, type II in 13 student (26,53\%), and type IV in 3 student (6,12\%). The conclusion of this research is rampant caries most of the students seen in the 5 years old and on female students. Type rampant caries most is the type III and the least that is the type IV.
\end{abstract}

Keywords : rampant caries, child

\begin{abstract}
Abstrak: Karies rampan merupakan salah satu masalah kesehatan gigi dan mulut yang sering terjadi pada anak. Hal ini memengaruhi pertumbuhan serta perkembangan gigi anak. Karies rampan sering ditemukan pada anak usia balita dan penyebaran tertinggi pada anak usia 3 tahun. Tujuan penelitian ini untuk mengetahui gambaran karies rampan pada siswa Pendidikan Anak Usia Dini di desa Pineleng II Indah. Penelitian yang dilakukan merupakan jenis penelitian cross-sectional study dengan sampel siswa yang berusia 3-5 tahun yaitu sebanyak 74 orang. Teknik pengambilan sampel yang digunakan ialah total sampling. Pemeriksaan karies rampan dilakukan dengan menggunakan kriteria $W H O$ kemudian didiagnosis berdasarkan tingkat perluasannya. Hasil penelitian menunjukkan bahwa tipe karies rampan yang paling banyak ditemui yaitu pada tipe III 19 siswa (38,78\%), kemudian terbanyak kedua ialah tipe I 14 siswa (28,57\%), terbanyak ketiga yaitu tipe II 13 siswa (26,53\%), dan yang paling sedikit yaitu tipe IV 3 siswa (6,12\%).Kesimpulan dari penelitian ini yaitu karies rampan paling banyak dijumpai pada siswa yang berumur 5 tahun dan pada siswa yang berjenis kelamin perempuan. Tipe karies rampan yang paling banyak yaitu tipe III dan yang paling sedikit yaitu tipe IV.
\end{abstract}

Kata kunci : karies rampan, anak

Kesehatan gigi dan mulut merupakan salah satu komponen dari kesehatan secara umum dan juga merupakan faktor yang penting dalam pertumbuhan normal dari anak. Masalah kesehatan mulut dapat memengaruhi perkembangan umum anak-anak, kesehatan tubuh secara umum dan juga dapat berdampak negatif terhadap kualitas hidup.Salah satu masalah kesehatan gigi dan mulut yang terjadi pada anakanak yaitu karies gigi. Karies dapat mengenai gigi 
sulung dan gigi tetap, tetapi gigi sulung lebih rentan terhadap karies karena struktur dan morfologi gigi sulung yang berbeda dari gigi tetap. ${ }^{1,2}$

Jenis karies gigi sulung yang umum terjadi yaitu karies rampan. Karies ini sering ditemukan pada anak usia di bawah lima tahun (balita), dengan penyebaran tertinggi pada anak usia tiga tahun. Kurangnya perhatian dan kesadaran orang tua akan pentingnya menjaga dan menanamkan kesehatan gigi dan mulut usia dini dapat berakibat pada masalah karies rampan yang dapat memengaruhi kualitas hidup bahkan pertumbuhan dan perkembangan gigi anak.Hal ini terjadi sangat cepat dan mengenai beberapa gigi serta sering menimbulkan rasa sakit, kesulitan makan dan gangguan berbicara. Jika tidak dirawat dapat memicu terjadinya kesulitan mengunyah karena sakit gigi atau kehilangan dini pada gigi sulung. ${ }^{3}$

Prevalensi karies rampan mencapai tingkat yang tinggi di berbagai negara dan keparahannya meningkat seiring pertambahan usia anak. ${ }^{4} \mathrm{Di}$ Indonesia, laporan mengenai kerusakan gigi sulung terutama karies rampan masih jarang dilakukan, walaupun observasi lapangan menunjukkan bahwa cukup banyak dijumpai karies rampan pada anak-anak prasekolah. Penelitian tentang karies rampan sangat diperlukan untuk menilai bagaimana keadaan kesehatan gigi dan keberhasilan upaya kesehatan gigi anak.

Prevalensi karies di Indonesia mencapai 90\% dari populasi anak balita. Menurut laporan penelitian oleh pengendalian dan pencegahan penyakit pada tahun 2007 menunjukkan bahwa karies gigi telah meningkat khususnya pada anak usia balita dan anak pra sekolah, yaitu dari 24\% menjadi $28 \%$ dimana pada anak usia 2 - 5 tahun meningkat $70 \%$ dari karies yang ditemukan. Data menurut Riset Kesehatan Dasar (RISKESDAS) tahun 2007 menunjukkan bahwa prevalensi karies di Sulawesi Utara menempati peringkat kedua tertinggi di Indonesia dengan persentase sebesar $57,2 \%{ }^{5}$

Desa Pineleng II Indah merupakan salah satu desa yang berada di kecamatan Pineleng, kabupaten Minahasa. Saat ini di kecamatan Pineleng terdapat 1 puskesmas namun belum ada tenaga dokter gigi, sehingga upaya-upaya dalam bidang kedokteran gigi masih kurang. Hal tersebut dapat menyebabkan kurangnya motivasi dan kesadaran dari orang tua untuk memeriksakan kesehatan gigi anak. Penelitian pada Pendidikan Anak Usia Dini (PAUD) yang berhubungan dengan kesehatan gigi dan mulut belum pernah dilakukan di Manado khususnya mengenai karies rampan, dan alasan peneliti melakukan penelitian pada anak usia 3-5 tahun karena umumnya gigi sulung anak telah tumbuh seluruhnya (telah berjumlah 20 gigi) sehingga karies rampanyang terjadi dapat dikelompokkan berdasarkan tingkat perluasannya.

\section{BAHAN DAN METODE}

Penelitian ini merupakan penelitian deskriptif dengan pendekatan potong lintang (crosssectional). Pengambilan sampel pada penelitian ini digunakan dengan menggunakan metode total sampling, yaitu mengambil semua siswa yang termasuk dalam kriteria sampel yaitu sebanyak 75 siswa. Pengumpulan data didahului dengan survey awal. Setelah dilakukan survei awal, dilanjutkan meminta izin kepada kepala sekolah untuk melakukan penelitian di PAUD Pineleng II Indah. Setelah disetujui oleh pihak sekolah, peneliti memberikan lembar persetujuan (informed consent) kepada wali kelas untuk diberikan kepada orang tua siswa. Setiap siswa yang telah memenuhi kriteria sampel dan telah memperoleh persetujuan oleh orang tuanya kemudian dipanggil dan duduk kemudian diperiksa.Pemeriksaan dilakukan menggunakan kaca mulut dan sonde setengah lingkaran. Pada setiap gigi dan hasil pemeriksaan dicatat pada lembar pemeriksaan yang tersedia bedasarkan kode dan kriteria menurut WHO, yaitu : d=karies, $\mathrm{e}=$ indikasi untuk pencabutan, $\mathrm{f}=$ tumpatan pada gigi, kemudian tentukan tipe karies rampan. Tim pemeriksa berjumlah 4 orang yang terdiri dari 2orang pemeriksa dan 2 orang pencatat. Sebelum pelaksanaan penelitian telah dilakukan kalibrasi pada tim pemeriksa.

\section{HASIL PENELITIAN}

Pada saat pemeriksaan dari 75 siswa PAUD desa Pineleng II Indah, 11 siswa PAUD desa Pineleng II Indah tidak hadir dalam penelitian jadi jumlah subjek yaitu 64 siswa. Jumlah subjek penelitian yang sesuai dengan kriteria memiliki jumlah yang berbeda antara laki-laki dan perempuan (Tabel 1). 
Tabel 1. Distribusi subjek penelitian berdasarkan jenis kelamin

\begin{tabular}{ccc}
\hline Jenis Kelamin & Jumlah (n) & Persentase (\%) \\
\hline Laki-laki & 29 & 45,31 \\
Perempuan & 35 & 54,69 \\
\hline Total & 64 & 100 \\
\hline
\end{tabular}

Pada tabel di atas dapat dilihat bahwa siswa PAUD Pineleng II Indah yang memenuhi kriteria untuk dijadikan subjek terdiri dari 29 orang (45,31 \%) yang berjenis kelamin laki-laki dan 35 orang (54,69 \%) yang berjenis kelamin perempuan.

Berdasarkan hasil penelitian di 2 PAUD desa Pineleng II Indah dengan subjek yaitu siswa yang berusia 3 sampai 5 tahun. Jumlah subjek penelitian yang sesuai dengan kriteria yaitu 64 orang yang bersekolah di PAUD desa Pineleng II Indah (Tabel 2).

Tabel 2. Distribusi subjek penelitian berdasarkan usia

\begin{tabular}{ccc}
\hline Usia (Tahun) & Jumlah (n) & Persentase (\%) \\
\hline 3 & 11 & 17,19 \\
4 & 27 & 42,19 \\
5 & 26 & 40,62 \\
\hline Total & 64 & 100 \\
\hline
\end{tabular}

Tabel 2 di atas menunjukkan karakteristik subjek penelitian berdasarkan usia yang terdiri dari 11 orang (17,19\%) berusia 3 tahun, 27 orang (42,19\%) berusia 4 tahun, dan 26 orang(40,64\%) berusia 5 tahun.

Tabel 3. Distribusi subjek penelitian berdasarkan ada-tidaknya karies rampan

\begin{tabular}{ccc}
\hline Karies rampan & Jumlah (n) & Persentase (\%) \\
\hline Ada & 49 & 76,56 \\
Tidak & 15 & 23,44 \\
\hline Total & 64 & 100 \\
\hline
\end{tabular}

Tabel 3 di atas menunjukkan bahwa siswa yang memiliki karies rampan lebih banyak yaitu 49 orang $(76,56 \%)$ dan yang tidak ada karies rampan yaitu 15 orang (23,44\%).

Setelah dilakukan pemeriksaan pada subjek penelitian maka dapat di kategorikan berdasarkan tipe karies rampan yaitu tipe I (karies melibatkan satu atau dua gigi anterior rahang atas), tipe II (karies melibatkan lebih dari dua gigi anterior rahang atas), tipe III (karies melibatkan satu atau dua gigi anterior rahang atas dan satu atau lebih gigi molar), tipe VI (karies melibatkan dua atau lebih permukaan gigi anterior rahang atas yang gigi dengan pulpa terbuka pada satu atau lebih gigi, dan karies telah terlihat pada gigi anterior rahang bawah) (Tabel 4).

Tabel 4. Distribusi subjek penelitian berdasarkan tipe karies rampan

\begin{tabular}{ccc}
$\begin{array}{c}\text { Tipe karies } \\
\text { rampan }\end{array}$ & Jumlah (n) & Persentasi (\%) \\
\hline I (minimal) & 14 & 28,57 \\
II (mild) & 13 & 26,53 \\
III (moderate) & 19 & 38,78 \\
IV (severe) & 3 & 6,12 \\
\hline Total & 49 & 100 \\
\hline
\end{tabular}

Data hasil penelitian yang didapatkan dari pemeriksaan menunjukkan bahwa pada karies rampan tipe I sebanyak 14 orang (28,57\%), tipe II sebanyak 13 orang (26,53\%), tipe III sebanyak 19 orang $(38,78 \%)$ dan tipe IV sebanyak 3 orang (6,12\%). Dari data tersebut menunjukkan bahwa yang paling banyak yaitu karies rampan tipe III dan yang paling sedikit yaitu karies rampan tipe IV.

Hasil pemeriksaan karies rampan pada 64 sampel dalam penelitian ini yang di kelompokkan berdasarkan usia (Tabel 5). Berdasarkan jenis kelamin terlihat bahwa pada siswa berjenis kelamin laki-laki menderita karies rampan tipe I sebanyak 5 orang (10,2\%), menderita karies rampan tipe II sebanyak 7 orang (14,28\%), menderita karies rampan tipe III sebanyak 6 orang (12,25\%) dan yang menderita karies rampan tipe IV sebanyak 3 orang (6,12\%). Pada siswa yang berjenis kelamin perempuan yang menderita karies rampan tipe I sebanyak 9 orang (18,37\%), menderita karies rampan tipe II sebanyak 13 orang (26,53\%), menderita karies rampan tipe III sebanyak 6 orang (12,25\%), dan tidak ada perempuan yang menderita karies rampan tipe IV. 
Tabel 5. Distribusi tipe karies rampan berdasarkan jenis kelamin

\begin{tabular}{cccccccccccc}
\hline Jenis & \multicolumn{1}{c}{ Tipe karies rampan } & \multicolumn{1}{c}{ Total } \\
\cline { 2 - 13 } kelamin & \multicolumn{3}{c}{ I } & \multicolumn{1}{c}{ II } & \multicolumn{1}{c}{ III } & \multicolumn{1}{c}{ IV } & \\
\cline { 2 - 13 } & $\mathrm{n}$ & $\%$ & $\mathrm{n}$ & $\%$ & $\mathrm{n}$ & $\%$ & $\mathrm{n}$ & $\%$ & $\mathrm{n}$ & $\%$ \\
\hline Laki-laki & 5 & 10,2 & 7 & 14,28 & 6 & 12,25 & 3 & 6,12 & 21 & 42,87 \\
Perempuan & 9 & 18,37 & 6 & 12,25 & 13 & 26,53 & 0 & 0 & 28 & 57,13 \\
\hline Total & 14 & 28,57 & 13 & 26,53 & 19 & 35,28 & 3 & 6,12 & 49 & 100 \\
\hline
\end{tabular}

Tabel 6. Distribusi tipe karies rampan berdasarkan usia

\begin{tabular}{|c|c|c|c|c|c|c|c|c|c|c|}
\hline \multirow{3}{*}{$\begin{array}{l}\text { Usia } \\
\text { (tahun) }\end{array}$} & \multicolumn{8}{|c|}{ Tipe karies rampan } & \multirow{2}{*}{\multicolumn{2}{|c|}{ Total }} \\
\hline & \multicolumn{2}{|r|}{ I } & \multicolumn{2}{|c|}{ II } & \multicolumn{2}{|c|}{ III } & \multicolumn{2}{|c|}{ IV } & & \\
\hline & $\mathrm{n}$ & $\%$ & $\mathrm{n}$ & $\%$ & $\mathrm{n}$ & $\%$ & $\mathrm{n}$ & $\%$ & $\mathrm{n}$ & $\%$ \\
\hline 3 & 2 & 4,09 & 1 & 2,03 & 4 & 8,16 & 0 & 0 & 7 & 14,28 \\
\hline 4 & 4 & 8,16 & 6 & 12,25 & 8 & 16,32 & 1 & 2,03 & 19 & 38,76 \\
\hline 5 & 8 & 16,32 & 6 & 12,25 & 7 & 14,3 & 2 & 4,09 & 23 & 46,96 \\
\hline Total & 14 & 28,57 & 13 & 26,53 & 19 & 38,78 & 3 & 6,12 & 49 & 100 \\
\hline
\end{tabular}

Data hasil penelitian yang didapatkan dari pemeriksaan karies rampan berdasarkan usia terlihat bahwa pada usia 3 tahun yang menderita karies rampan tipe I sebanyak 2 orang (4,09\%), menderita karies rampan tipe II sebanyak 1 orang (2,03\%), menderita karies rampan tipe III sebanyak 4 orang $(8,16 \%)$, dan tidak ada yang menderita karies rampan tipe IV. Pada anak usia 4 tahun yang menderita karies rampan tipe I sebanyak 4 orang (8,16\%), menderita karies rampan tipe II sebanyak 6 orang $(12,25 \%)$, menderita karies rampan tipe III sebanyak 8 orang $(16,32 \%)$, dan menderita karies rampan tipe IV sebanyak 1 orang (2,03\%). Pada anak usia 5 tahun yang menderita karies rampan tipe I sebanyak 8 orang (16,32\%), menderita karies rampan tipe II sebanyak 6 orang (12,25\%), menderita karies rampan tipe III sebanyak 7 orang (14,3\%), dan menderita karies rampan tipe IV sebanyak 2 orang (4,09\%) (Tabel 6).

Berdasarkan hasil penelitian di 2 PAUD desa Pineleng II Indah dengan indeks def-t yaitu indeks $\mathrm{d}$ (decayed) berjumlah 233, e (indicated for extracted) berjumlah 44 dan tidak ada gigi $\mathrm{f}$ (filled) (Tabel 7).

Data hasil penelitian menunjukkan indeks def-t rata-rata untuk 64 siswa dari 2 PAUD yaitu PAUD Genesis dan PAUD Esa Toroan di desa Pineleng II Indah sebesar 4,3. Berdasarkan kriteria dari WHO, indeks ini berada pada kategori status karies sedang.

Tabel 7. Distribusi frekuensi indeks def-t

\begin{tabular}{ccc}
\hline Indeks & $\mathrm{n}$ & $\%$ \\
\hline $\mathrm{d}$ & 233 & 84 \\
$\mathrm{e}$ & 44 & 16 \\
$\mathrm{f}$ & 0 & 0 \\
\hline Jumlah & 277 & 100 \\
\hline
\end{tabular}

\section{BAHASAN}

Subjek yang diteliti pada penelitian ini yaitu siswa PAUD di Desa Pineleng II Indah yaitu PAUD Genesis dan PAUD Esa Toroan. Subjek penelitian tersebut meliputi siswa yang berusia 3 sampai 5 tahun. Penetapan usia yang digunakan pada penelitian ini dihitung berdasarkan terakhir kali subjek berulang tahun. Jumlah sampel yang memenuhi kriteria yaitu 64 orang. Hasil penelitian yang dibagi berdasarkan jenis kelamin seperti yang terlihat pada Tabel 1 menunjukkan bahwa sampel yang berjenis kelamin laki-laki 29 orang (45,31\%) dan perempuan 35 orang (54,69\%). Subjek yang berusia 4 tahun memiliki jumlah terbanyak yaitu 27 orang (42,19\%), terbanyak kedua yaitu sampel yang berusia 5 tahun yaitu sebanyak 26 orang (40,62\%), 
terbanyak ketiga yang berusia 3 tahun yaitu sebanyak 11 orang $(17,19 \%)$.

Berdasarkan data yang di dapat paling banyak siswa yang mengalami karies rampan yaitu berjumlah 49 siswa (79,56\%) sedangkan siswa yang tidak mengalami karies rampan berjumlah 15 siswa (23,44\%). Hasil ini konsisten dengan penelitian yang dilakukan Broderick pada tahun 1989 yang menyatakan bahwa 70\% anak-anak usia 3-5 tahun mengalami karies rampan dan $30 \%$ anak yang tidak mengalami karies rampan. ${ }^{6}$ Hasil yang sama ditunjukkan pada penelitian Awooda pada tahun 2013 yang menunjukkan 64,6\% anak taman kanakkanak di berbagai wilayah negara Khartoum melalui pemeriksaan klinis menggunakan kriteria WHO memiliki karies gigi, sedangkan 35,4\% anak bebas karies. ${ }^{7}$

Berdasarkan hasil penelitian didapatkan yang paling banyak yaitu karies rampan tipe III dan yang paling sedikit yaitu karies rampan tipe IV. Salah satu faktor resiko dari karies rampan yaitu faktor perilaku diet. Pola pemberian makan tertentu, seperti penggunaan botol susu pada waktu tidur, menyusui, dan seringnya memberi minuman yang mengandung gula berkontribusi terhadap perkembangan karies rampan. Pada siswa PAUD Desa Pineleng II Indah yang paling banyak menderita karies rampan tipe III berdasarkan penelitian American Academy of Pediatrics menyatakan bahwa bayi yang dibiarkan tertidur dengan botol susu maupun menyusui ASI sepanjang malam beresiko tinggi terjadi karies gigi. Pemakaian botol susu pada bayi merupakan faktor predisposisi karies rampan karena dot dapat menahan saliva pada gigi insisivus rahang atas, sedangkan gigi insisivus rahang bawah yang dekat dengan kelenjar ludah tidak terkena. ${ }^{8}$ Pada pemeriksaan dapat dilihat kerusakan yang paling parah yaitu pada keempat gigi insisivus maksila, gigi insisivus maksila merupakan gigi yang pertama erupsi pada rahang atas sehingga gigi insisivus maksila akan terlebih dahulu mengalami serangan karies dan juga akan menjadi gigi yang paling lama mengalami karies rampan.

Berdasarkan jenis kelamin, didapatkan dari hasil pemeriksaan anak perempuan menderita karies rampan lebih tinggi dari anak laki-laki (Tabel 5). Hasil penelitian Pontonuwu J di Tomohon menunjukkan bahwa status karies pada perempuan lebih tinggi daripada laki-laki. ${ }^{9}$ Penelitian serupa yang dilakukan oleh Tulangow J menunjukkan jumlah anak laki-laki lebih banyak mengalami karies dari anak perempuan. ${ }^{10}$ Hasil penelitian dari Sihombing, tentang karakteristik penderita karies gigi di RSU Dr. Pirngadi di Medan, menunjukkan bahwa pengalaman karies lebih tinggi pada wanita daripada pria selama periode anak-anak sampai remaja. $^{11}$

Berdasarkan usia, pada Tabel 6 memberikan gambaran bahwa usia responden yang paling banyak menderita karies rampan yaitu usia 5 tahun sebanyak 23 siswa (46,96\%).Berdasarkan penelitian sebelumnya yang dikemukakan Zaura pada tahun 2007 di negara-negara berkembang seperti Asia termasuk di Indonesia, bahwa anak-anak umur 5 tahun ke atas 80-90 \% mengalami kerusakan gigi. Menurut peneliti pada usia 5 tahun ke atas anak mulai memakan makanan yang dilarang dan masa tersebut anak paling banyak menderita gigi karies dentin kemungkinan karena pola makan yang kurang teratur dan ketidaktahuan menjaga kesehatan gigi sehingga dapat menyebabakan terjadinya karies gigi. ${ }^{28}$ Pada usia 5 tahun anak masih membutuhkan bimbingan dari orang tua untuk mengingatkan makanan dan minuman apa yang menyebabkan karies rampan dan bagaimana cara mencegah terjadinya karies rampan dengan berkumur maupun menyikat gigi secara teratur 3 kali sehari.

Data hasil penelitian menunjukkan rata-rata indeks def-t untuk 64 siswa dari dua PAUD di desa Pineleng II Indah yaitu 4,3, yang berdasarkan kriteria dari WHO, indeks ini berada pada kategori status karies sedang. Hasil ini konsisten dengan penelitian yang dilakukan Kornileani pada tahun 2004 menunjukkan hal yang sama, dimana di Taman Kanak-kanak Islam Hidayahtullah Semarang memiliki indeks karies kategori sedang yaitu 2,78. ${ }^{12}$ Frekuensi mengonsumsi makanan dan minuman yang manis dengan tidak disertai rutin menggosok gigi bahkan berkumur setelah mengonsumsi makanan dan minuman tersebut akan memicu timbulnya karies. Orang tua siswa mengaku bahwa anak mereka sering mengonsumsi asi, makanan dan minuman yang manis seperti susu formula, teh manis, jus, soft drink, permen, cokelat dan makanan ringan. Ada sekitar $75 \%$ siswa juga tidak dibiasakan menyikat gigi bahkan berkumur setelah mengonsumsi makanan dan minuman yang manis.

Siswa yang menjadi sampel pada penelitian ini yaitu berusia 3 sampai 5 tahun yang artinya masih 
dalam periode gigi sulung. Tidak adanya pengetahuan, informasi dan perhatian tentang bagaimana pentingnya menjaga kesehatan gigi dan mulut mulai dari usia anak sekolah yang diberikan oleh orang tua maupun tenaga pengajar disekolah menyebabkan besarnya resiko terjadinya karies rampan pada penelitian ini. Orang tua dan tenaga pengajar disekolah harus mengerti akibat yang timbul akibat pemberian minuman dan makanan manis agar bisa mencegah karies rampan. Orang tua dapat mengurangi risiko terjadinya karies gigi dengan melakukan cara pencegahan karies dengan berkumur dengan air bersih setelah minum susu maupun makan makanan yang manis dan menggosok gigi untuk menjaga kebersihan gigi dan mulut. Orang tua juga harus membiasakan anaknya memeriksakan gigi mereka ke dokter gigi 2 kali dalam 1 tahun. Para pengajar disekolah juga berperan penting dalam menjaga kesehatan dan kebersihan rongga mulut siswanya dengan mengajarkan cara menggosok gigi yang baik dan benar, waktu menyikat gigi yaitu pada saat pagi setelah sarapan pagi dan malam sebelum tidur. Pihak sekolah juga dapat membuat programprogram untuk kebersihan dan kesehatan gigi, contohnya dengan membuat penyuluhan dan pemerikasaan gigi yang berkoordinasi dengan pihak puskesmas terdekat dan juga program menyikat gigi bersama setiap minggu.

\section{SIMPULAN}

Berdasarkan penelitian yang telah dilakukandi PAUD Genesis dan PAUD Esa Toroan desa Pineleng II Indah, maka diperoleh kesimpulan yaitu karies rampan paling banyak dijumpai pada siswa yang berumur 5 tahun dan yang berjenis kelamin perempuan.Tipe karies rampan yang paling banyak ditemui yaitu tipe III, kemudian terbanyak kedua ialah tipe I, terbanyak ketiga yaitu tipe II dan yang paling sedikit yaitu tipe IV.

\section{SARAN}

Diharapkan adanya penelitian lebih lanjut untuk dapat memperoleh gambaran karies rampan pada anak pendidikan usia dini yang berada di kabupaten Minahasa khususnya di desa Pineleng. Bagi sekolah diharapkan dapat menyediakan fasilitas seperti UKS/UKGS untuk dapat menunjang upaya pelayanan kesehatan. Bagi Orang tua diharapkan lebih memperhatikan dan menjaga kesehatan gigi dan mulut dengan mengajarkan dan mengingatkan anaknya menyikat gigi secara benar dan teratur.

\section{DAFTAR PUSTAKA}

1. Annerosa B, Maik W, Sussane K. Early childhood caries: a multi-factoral disease. OHDMBSC 2010;9(1):p. 32-8.

2. Andrijana C, Mirjana I. The role of streptococcus mutans group and salivary immunoglobullins in etiology of early childhood caries. Stom glass 2006:p. 113-7.

3. Fatemeh M, Maryam T, Musa Z. Prevalence of early childhood caries and its risk factors in 6-60 months old children in Quchan. Dent res J 2007;4(2):p. 96-101.

4. Jean-March B, Chantal G. The high incidence of early childhood caries in kindergartenage children. JODQ 2006:p. 4.

5. RISKESDAS. [serial online] 2007 [2013 Oktober 12]. Available from: URL: http://www.litbang.depkes.go.id/laporanRK D/Indonesia/Riskesdas_2007_English.zip

6. Broderick E, Mabry J, Robertson D, Thompson J. Baby bottle tooth decay in native American children in Head Start Centers. Public Health Reports 1989;104(1):p. 50-3.

7. Awooda E, Saeed S, Elbasir E. Caries prevalence among 3-5 years old children in khartoum State-Sudan. IJMHS 2013; p. 423.

8. Ivo A. Early childhood caries (ECC). [serial online]. [2013 agustus 15]; Available from URL:

http://repository.usu.ac.id/bitstream/123456 789/8602/1/09E00832.pdf

9. Pontonuwu J. Gambaran status karies anak sekolah dasar di kelurahan Kinilow 1 kecamatan Tomohon Utara [serial online]. 2013 [2013 juni 22] . Available from URL http://ejournal.unsrat.ac.id/index.php/egigi/a rticle/view/3145

10. Tulangow J. Gambaran status karies murid sekolah dasar negeri 48 Manado berdasarkan status sosial ekonomi orang tua [serial online]. 2013 [2013 juni 23 ]. Available from URL ejournal.unsrat.ac.id/index.php/egigi/article/ download/2621/2174

11. Sihombing J. Karakteristik penderita karies gigi yang berobat di Rumah Sakit Umum 
Dr. Pirngadi. Medan: USU. [Online]. 2009 [2013 juni 23]. Available from URL: http://repository.

usu.ac.id/bitstream/123456789/14660/1/09E 01300.pdf.

12. Korneliani K. Hubungan tingkat konsumsi karbohidrat dan kesukaan makanan kariogenik anak usia pra sekolah dengan terjadinya karies gigi di taman KanakKanak Islam Hidayatullah Semarang [serial online]. 2004 [2014 oktober 4]. Available from URL http://eprints.undip.ac.id/6215/1/2117.pdf 